\title{
Pan-Turkism and Discussion on Muslim National School in the Middle Volga Region After 1905
}

\author{
Galina V. Rokina ${ }^{1} \&$ Oxana B. Zemtsova ${ }^{1}$ \\ ${ }^{1}$ Mari State University, Yoshkar-Ola, Russia \\ Correspondence: Galina V. Rokina, Laboratory of Ethnic and Gender Studies, Mari State University, 32 A., \\ Uspenskaia str., Yoshkar-Ola, 424006, Russia. E-mail: galina@rokina.ru
}

$\begin{array}{lc}\text { Received: February 21, } 2015 & \text { Accepted: March 15, } 2015 \quad \text { Online Published: April 29, } 2015 \\ \text { doi:10.5539/res.v7n8p95 } & \text { URL: http://dx.doi.org/10.5539/res.v7n8p95 }\end{array}$

\begin{abstract}
This article examinesthe situation in the Muslim school (madrasah) in the Middle Volga region after 1905 and changing aspirations of Russians towards the acculturation of Muslims connected with it. The fears and suspicions of the Russian authorities concerned the development of cultural ties between Russian and Turkish Muslims, which legitimized the idea that these ethnic groups could unite in a new political entity on the basis of common religion or on a common ethno-linguistic basis (Turkish). Much of the blame for the spread of Pan-Turkic and Pan-Islamic ideas was placed upon the new method schools of the region. Muslim traditional educational system also underwent changes which particularly involved teaching of the Russian language and other secular subjects. While Muslim community continued to reform their educational system, the local authorities continued to question the idea of the Muslim "national"school.
\end{abstract}

Keywords: Pan-Turkism, national school, nationalism, language teaching

\section{Introduction}

The politicization of Muslim consciousness in the 1905 period alerted the authorities' attention to the existence of global movements such as Pan-Islamism and Pan-Turkism. Although warning voices of the existence of such phenomena in Russia had been heard since the late nineteenth century, neither of them had really developed into a coordinated movement. In fact, the authorities would often exaggerate the actual threat that Pan-Islamic or Pan-Turkic ideas posed. However, it is clearthat the overall attitude to Muslims deteriorated rapidly after the Young Turks revolution of 1908. And, although in the majority of cases the authorities acknowledged the loyalty of Muslim clergy, they found the appearance of Muslim political and nationalist activists quite disturbing. In fact, the Ministry of the Interior checked each candidate for the position of mullah for political reliability.

Contemporary historiography of the Middle Volga region is clearly dominated by works devoted to the Muslim subjects of the empire.Kemal Karpat's presentation of Russia's Eastern provinces as likely targets for the spread of Pan-Islamism explains the particular anxiety of the empire concerning the Tatar population and religious and educational activities of its respective elites (Karpat, 2001). It shows that considerable change was taking place among the Muslim population.

When analyzing the reaction of the Middle Volga Muslims to the policies introduced by the center, the topics that deserve greatest attention are the appearance of reforms in the Muslim milieu and the subsequent emergence of jadidism(new method) which, born as a movement within an educational framework, later called for social changes and Muslim mobilization. Several works deal with the dichotomy of jadid-qadimist schools in the Middle Volga region.For instance, Stephan Dudoignon sees the qadims (the followers of the old method) as a conservative part of the Muslim umma, which tried to preserve the unity of the Muslim community at a time of dramatic changes (Dudoignon, 1997). A Japanese researcher NorohiroNaganawa compares the Muslim educational institutions in Kazan, Ufa and Orenburg provinces and demonstrates how the Ural-Volga Muslims were involved in the national project of universal primary education. He also examines different strategies that Muslim intellectuals and villages employed in relations with the state institutions in general and zemstvos in particular. Criticizing the somewhat stereotypical view of conservative Muslim resistance to zemstvo schools, Naganawa gives new insights into the "unique cooperative relationships between the local self-government and the Muslims" (Naganawa, 2006). 
Allen Frank and Michael Kemper have demonstrated that the Muslims of the Volga-Urals developed a distinct regional Islamic identity. At the center of the discussion in Frank's work on the identity of the Volga Tatars is the way Tatar and Bashkir ulama conceived of their history. He argues that the Muslims of the Volga basin should be regarded as a single religious community originating in thetenth century when the population of city of Bulghar converted to Islam. Supporting this view, Frank claims that, although from the eighteenth century onwards, the Bulgharist approach to Muslim identity was questioned, the ulama of the region barely differentiated Tatars and Bashkirs in ethnic or linguistic terms (Frank, 1998). A Tatar scholar DamirIskhakov argues against this point of view, supporting the idea that the Middle Volga Muslims have an ethnic consciousness based on memories of the golden Horde, being Turkic-speaking Tatars (Iskhakov, 1997). These are undoubtedly the main issues relevant to an understanding of the way Tatar nationalism developed.

While the reforms were bringing changes into the life of the entire population of the Russian empire, its Muslim subjects experienced changes both from outside and within their communities. Among all the non-Russian minorities of the Middle Volga, Muslim Tatars were the only ethnic group who put forwardtheir own nation-building project. Growing Muslim nationalism was closely connected to schooling, this is why this subject merits a separate discussion. For this reason, this article is devoted to the post-1905 school reforms when both the state school and traditional madrasah of the Middle Volga Muslims underwent significant modifications.

\section{Methods}

In our research we have used both published sources and archival sources located in the cities of Moscow, St. Petersburg and Kazan. The Special Department (Osobyiotdel) fund of the State Archives of the Russian Federation (GosudarstvennyiarkhivRossiiskoiFederatsii, or GARF, for short) in Moscow contains files on the Muslim movement including materials about various unions and organizations. A rich collection of documents is stored in Russian State Historical Archives (RossiiskiiGosudarstvennyiIstoricheskiiarkhiv, RGIA) in St. Petersburg.

Sourcesproviding a clearer picture of the situation on the ground are kept in the National Archives of the Republic of Tatarstan (Natsional'nyiarkhiv Respubliki Tatarstan, NART) in Kazan. Among the sources studied in these archives are the files of the fund of the Kazan Provincial Administration (Kazanskoegubernskoepravlenie, years 1798-1917) enclosing documents on appointing mullahs, building mosques, apostasies and conversions to Orthodoxy, and conversions to other religions. The files of Kazan Ecclesiastical Academy (Fund Ten, Kazanskaia Dukhovnaiaakademiia, 1842-1920) are filled with reports on missionary activities of the academy, teaching programs, and reports on schools in the region, documents on teaching Tatar, Arabic, Mongolian and other languages.

Many documents concerning educational matters among the non-Russians of the region are contained in Fund 92 of the Curator of Kazan Educational District (1802-1918). Starting from 1888, the district covered educational institutions of Astrakhan, Kazan, Viatka, Simbirsk, Samara and Saratov provinces. The files of the fund include the circulars of the curator, minutes of school committees and yearly reports, documents concerning the level of education among the Tatar and the Bashkir population as well as letters about the obligatory introduction of the Russian language in the madrasah.

Finally, the files of Kazan Tatar Teacher Training College (Kazanskaiatatarskaiauchitel'skaia shkola, 1893-1918, Fund 142) allow us to understand how this college, the institution organized exclusively for Muslims, trained teachers for Russian-Tatar schools of the region as well as teachers of Russian for madrasahs and mektebs. Much like for other educational institutions, the files contain yearly reports, teaching timetables and correspondence on school matters. The documents concerning teachers and graduates of the college are among the most useful files for the analysis of the role of the college in the lives of the Middle Volga Muslims.

\section{Results}

The fears and suspicions of the Russian authorities concerned the development of cultural ties between Russian and Turkish Muslims, which legitimized the idea that these ethnic groups could unite in a new political entity on the basis of common religion or on a common ethno-linguistic basis (Turkish). Indeed, Petr Stolypin, who was appointed Prime Minister in 1906, viewed the "Muslim question" not as a religious question but rather as a cultural and state issue. On 19 September 1909, he wrote to the Ober-Procurator of the Holy Synod S. M. Luk'ianov that the propaganda of Pan-Islamism, as well as any other Muslim activity in any part of the empire, merited serious attention and possible counteraction from the government:

Turning to Povolzh'e and the district of Kazan, I cannot help mentioning that we must make serious efforts to resist the Tatar national onslaught in this region with its non-Russian population which wavers between Russian 
Orthodox and Muslim Tatar influence. To give up this struggle would mean to give up all the centuries-old historical tasks, the negative consequences of which would be incalculable (Note 1).

To control the activities of mullahs on the level of the Spiritual Assembly (the highest official Muslim body of the empire), the head of the department of religious Affairs of Foreign Faiths Alexei Kharuzin sent an inspection in June 1910 in order to find out if the Assembly was responsible for any possible inclination towards Pan-Islamism or supported the new-method schools. I. M. Platonnikov, the person in charge, spoke to the members of the Assembly and examined the correspondence of the Assembly, which was in complete disorder. What he deduced from his inspection was that the activity of the Assembly was incompatible with the interests of the Russian government and did not even satisfy the needs of the Muslim population (Note 2).

This issue was discussed at a special Interministerial conference summoned by Stolypin and chaired by Kharuzin in 1910. There was a general feeling that the "rigidly consistent program of religious and cultural unification of all the Muslim population of Russia, fully independent of the government in matters of religion and school on the principle of autonomy under the control of a religious leader" which was "scheduled by Muslim leaders"should be considered quite dangerous (Alov, 1996). The governor of Viatka, P. Kamyshanskii, argued that it should be the task of the government to support the "cleanliness of Islam", which should be protected from reformist political and educational ideas, since Muslims who renounce qadimist principles were likely to become "revolutionaries who dream of overthrowing autocracy" (Note 3).

After the conference Kharuzin wrote a report which was to reflect the ideas of the conference participants about the ambitions and cultural aspirations of Middle Volga Tatars. In this reportKharuzin accused Tatar nationalists of spreading "anti-state" Pan-Islamic and Pan-Turkic ideas. He would use the terms "Pan-Islamism" and "Pan-Turkism" interchangeably, stressing that the contacts of the Volga Tatars with Muslims from other countries were the main reason for the spread of these expanding "movements".

As far as Muslim confessional schools were concerned, the conference participants admitted that new schools hardly served the interests of the empire, instead of bringing Muslim Tatars closer to Russians, new-method schools teaching Turkish, and the history and geography of Turkey were widening the gap. It was decided that the new-method schools should be taken under stricter control. All schools with non-confessional subjects were now supposed either to drop them or close. Subsequently, the police started a campaign of raids searching for the instigators of Pan-Islamic and Pan-Turkic propaganda. In 1911 alone over 150 raids were conducted in the Volga region, which resulted in the closing of about 70 institutions, among which were schools, publishing houses and various community organizations (Note 4).

Apparently, many people thought that ideas of Pan-Turkism were imposed on the Russian Muslims from outside and were the result of the external threat coming from the Ottoman Empire rather than due to internal ideological reforms in the Muslim milieu. This explains the police investigations into possible pro-Ottoman sentiments in madrasahs and mosques, which increased after the Young Turk revolution. For instance, Mukhammadiia madrasah in Kazan was often the subject of police investigation. Its founderand director GalimzhanGaleevBarudi had introducedsecular subjects along with the traditional religious subjects in the teaching program. The madrasah offered the shakirds (students) Arabic, Turkish and Russian, law, history of Russia and Turkic people's history (istoriiatiurkskikhnarodov) among other subjects.

In 1905, Muslim schooling remained an actively discussed issue since the development of the new-method school was often seen as the embodiment of rising Muslim nationalism. The new-method schools, although teaching the Russian language, were drawing Muslims away from Russians on the issue of acculturation. There was a general fear that new schools were developing a worldview that would make Muslim Tatars associate more with Turkey than with Russia. Secularisation of a Muslim school could transform the Muslim question from a religious to a political one and turn religious "fanatics" into Pan-Turkic or Pan-Islamic leaders. Besides, introduction of general subjects at madrasahs would keep Muslims from sending their children to Russian-Tatar schools further widening the gap between Russians and Tatars rather than bridging it.

Among all the non-Russian ethnic groups of the Middle Volga region, the Tatars were the ones who most eagerly accepted the opportunity to participate in the reforms on the imperial agenda, to promote their national interests. After 1905 jadidism (the new method movement, initially standing for a teaching method that would bring the students to actually read texts instead of memorising them) spread across the whole set of values of Tatar society. Changes touched upon every sphere of life, even the way people dressed and behaved in their every-day life. And even if the term "jadidism" spread out of the classroom and started to be used for all the innovations in Tatar society, the idea of Muslim education remained closely linked to the idea of nationhood.

This was widely discussed at the Third Muslim congress in Nizhnii Novgorod in 1906. A special report of the 
committee, elected by the congress participants, contained 33 points. We will now take a closer look at some of them. Besides general ideas about the necessity of schools for Muslims, more specific points focused on demands concerning the language of education, which was to be in the mother tongue with the use of the Arabic alphabet.Studying Russian in the primary school was considered unnecessary, and even in the secondary school it was to be but a school subject, not the language of education. Instead, major emphasis, both in gymnasiums and teacher training schools with Russian language education, was to be put onto the study of Islam and the literary native languages (Tatar, Bashkir, Kirghiz) so that the Muslims who graduated from these schools could teach children later.

Special attention was paid to the literary Turkish language, which was to be introduced not only in the secondary schools, but also in primary school wherever possible. Literary Turkish was seen as the language that could potentially unite Russian Muslims both among themselves and with the Ottoman Turks. It was desirable that young Russian Muslims should begin to study literary Turkish as early as possible. The project, outlined by the congress, was to create a "Muslim national school" (Koblov, 1916).

The head diocesan missionary with responsibility for combatting Islam and animism (from 1901), Ia. Koblov, was extremely suspicious of the idea. In a booklet entitled "Dreams of Muslim Tatars about the National School", he warned the reader that Tatars, being "most extreme nationalists", keep almost exclusively to their national goals and behave in a suspicious and negative way towards people of another faith, being barely influenced by co-existence with other ethnic groups, but effectively assimilating (pretvoriia $v$ sebia) weaker ethnic groups (Koblov, 1908). In his book, Koblov touches upon an important question; whether it is possible to speak of a "Muslim national school" at all. The idea of assigning the definition "national" to a Muslim confessional school certainly demonstrates an attempt at unification of

Islamic people on the basis of common religion but, to Koblov, religion and ethnicity were two distinct categories. This is why he claimed that even the question of the national school itself was absurd, for there could be no national Muslim school, there only could be national schools of ethnic groups professing Islam: Bashkir, Kirghiz, Votiak - which would satisfy not only the religious but also the general spiritual needs of the people according to their peculiarities.

Among the above-mentioned Muslim ethnic groups (Tatars, Bashkir, Kirghiz), the Tatars were more advanced and found themselves in a privileged position. In fact, the ethnic name "Tatar" had been long used as synonymous with "Muslim", and the two words would sometimes be used interchangeably by the local population. Thus, if Tatar was voted the language of schooling, because it already had a rich literature, schools for Bashkir or Kirghiz would immediately become non-national. Koblov suggested that, although the idea of a Muslim "national" school seemed absurd, itwas possible to have separate schools for each ethnic group in their mother tongue. This would separate groups of Muslims, or at least, prevent them from unifying.Koblov's reasoning shows that by this time the official discourse on ethnicity had undergone considerable evolution. It is no longer described or limited by confession but included cultural and anthropological categories. Religion and ethnicity, in this case "Muslim" and "Tatar", "Bashkir", "Kirghiz"were seen as separate categories.

In fact, like many other missionaries in Kazan diocese, Koblov feared that the projected"national" school would in reality not be national, but Muslim confessional, and in the Middle Volga region it was likely to become a Muslim Tatar school with the introduction of general subjects. The authorities would not dream of strengthening a Muslim nationality, Tatar in this case, nor would they allow Muslim ethnic groups to unite, even when it came to schooling. Although Muslims earned a reputation as loyal Russian citizens, it did not mean that the government would rush to finance, or to take care of, Muslim schools.

As Alexandre Bennigsen claimed, ideas of nationalism in the modern sense of the term were not yet established among Russian Muslims before the October Revolution (Bennigsen, 1971). Russian Muslims identified themselves not in ethnic but in religious terms, as the community of believers. The problem with the Tatar understanding of "national" education could be attributed to the beliefs of Islam. Members of the Muslim umma are not divided into national or ethnic groups, for they oppose themselves only to al-kafirun, the non-believers, those who do not believe in Islam, no matter what nationality or state al-kafirun belong to. Given this perception, when Tatars spoke about a Muslim "national" school, they probably did not take into consideration the ethnicity of the members of the umma, calling "national" what should really be called"confessional".

Among the most advanced madrasahs at that time were Bubimadrasah in the district of Sarapul (present-day Bashkortostan), Khusaniia in Orenburg, Usmaniia in Ufa, Galiia, Mukhammadiia and Apanaevskaia in Kazan. In addition, the following new-method schools of Kazan were quite well-established: Mardzhani, Alimov, Usmanov and also Amirkhan and Mansur. The last two were still at the level of mekteb (a lower-level school), 
for they had an unequal duration of studies which was a drawback left over from the old-method school. There was, however, an extension as to the notion of the "new method school". If one speaks only of the reading method then the majority of Muslim schools in the Middle Volga region were already new-method ones by 1906. Ifinstead, one has in mind the spread of general education, there were different "stages" of madrasah development, which usually depended on the teacher's knowledge. This meant that a new-method school could often be recognized as such if the teacher was knowledgeable and taught general education subjects. Unfortunately, once that teacher left the school, it easily turned back to an old-method one. Thus, although Muslims were aware of the necessity of general subjects, the majority of their new method schools still remained confessional with additional general subjects. The Russian language was often taught as a supplementary subject and the major stress was put into teaching Turkish and Turkish literature.

Let us now have a look at curricula of the two most popular madrasahs - the Bubi and the Mukhammadiia (Makhmutova, 2003).

Table 1. The weekly time-table of Bubi Madrasah compared to Mukhammadiia (1906)

\begin{tabular}{|c|c|c|c|c|c|c|c|c|c|c|c|c|c|c|}
\hline \multirow[t]{2}{*}{ Subjects } & \multicolumn{7}{|c|}{ Bubi } & \multicolumn{7}{|c|}{ Mukhammadiia } \\
\hline & 1 & 2 & 3 & 4 & 5 & 6 & Total & 1 & 2 & 3 & 4 & 5 & 6 & Total \\
\hline Arabiclanguage & 3 & 3 & 3 & 3 & 2 & 2 & 16 & & 7 & 7 & 7 & 8 & 4 & 33 \\
\hline Turkic (Tatar) & 3 & 1 & & & & & 4 & 6 & 3 & 3 & 2 & & & 14 \\
\hline Persian & 1 & 1 & 1 & & & & 3 & & & & & & & \\
\hline Geography & 2 & 2 & & & & & 4 & & 2 & 2 & 2 & 2 & & 8 \\
\hline Generalhistory & & 2 & 2 & 2 & 2 & 2 & 10 & 1 & 1 & 1 & 1 & 2 & & 6 \\
\hline Ethics & 1 & 1 & 2 & 1 & & & 5 & 1 & 1 & 1 & 1 & & & 4 \\
\hline Logic & & & 1 & & & & & 1 & & & & & 2 & 2 \\
\hline Arithmetic & 4 & 4 & 4 & & & & 12 & 2 & 2 & 2 & 2 & 2 & & 10 \\
\hline Algebra & & & & 2 & 2 & 1 & 5 & & & & & & & \\
\hline Geometry & & & & 2 & 2 & 2 & 6 & & 1 & 1 & 1 & 1 & & 4 \\
\hline Physics & 3 & 3 & 2 & & & & 8 & & & & & & & \\
\hline Astronomy & & & & & 2 & & 2 & & & & & & & \\
\hline Naturalsciences & & & & 2 & 2 & 2 & 6 & 1 & 1 & 1 & 1 & & & 4 \\
\hline Zoology & & & & & 1 & & 1 & & & & & & & \\
\hline Botany & & & & & & 1 & 1 & & & & & & & \\
\hline Chemistry & & & & & 2 & 2 & 4 & & & & & & & \\
\hline Mineralogy & & & & & & 1 & 1 & & & & & & & \\
\hline Figh & & 1 & 1 & 1 & 1 & 1 & 5 & & & & & 3 & & 3 \\
\hline Oratoryart & & & & & & 1 & 1 & & & & & 2 & & 2 \\
\hline MuslimTheology & & & & 2 & 1 & 1 & 4 & 1 & 1 & 2 & 3 & & 2 & 9 \\
\hline Calligraphy & 1 & 1 & 1 & & & & 3 & 2 & 1 & 1 & 1 & 1 & & 6 \\
\hline Hygiene & & & & & 1 & 1 & 2 & 1 & 1 & & & & & 2 \\
\hline Russian & 12 & 12 & 12 & 12 & 12 & 12 & 72 & & Stud & d in & $\mathrm{Ru}$ & an-1 & $\operatorname{tar}$ & chool \\
\hline Qur'an & & & & & & & & 3 & 2 & 2 & 1 & & 3 & 11 \\
\hline Hadith & & & & & & & & 1 & & & & 2 & 3 & 6 \\
\hline Pedagogy & & & & & & & & & & & & & 2 & 2 \\
\hline Law & & & & & & & & & & & & & 1 & 1 \\
\hline Politicalhistory & & & & & & & & & & & & & 1 & 1 \\
\hline Historyofphilosophy & & & & & & & & & & & & & 1 & 1 \\
\hline Economy & & & & & & & & & & & & & 1 & 1 \\
\hline Total & 30 & 32 & 30 & 28 & 28 & 31 & 179 & 20 & 23 & 23 & 22 & 22 & 20 & 130 \\
\hline
\end{tabular}


Both the Bubi brothers of the "Bubi" and GalimdzhanBarudi of "Mukhammadiia" certainly belonged to the jadid group of educators. But there were differences. Eastern languages and Qur'anic studies took 86 hours out of 130 that is two-thirds of the teaching time at Barudi's madrasah (although we should add the Russian language classes held in the Russian Tatar School to the remaining one-third). Still, very little time was devoted to general education subjects in comparison to the Bubimadrasah (with only 39 hours of religious studies and eastern languages and 140 hours of general education subjects, which included 72 hours of Russian). Moreover, in the Bubi madrasah, if we look at the general subjects, some part of this timewas devoted to subjects of a practical nature (botany, zoology, chemistry, mineralogy), which could be useful in the rural environment. The Bubi brothers liked to experiment and did not hesitate to introduce innovations into the curriculum of their school, as can be seen from the table below showing the timetable from only two years later.

Table 2. The weekly time-table of the Bubi Madrasah, 1908

\begin{tabular}{|c|c|c|c|c|c|c|c|c|c|}
\hline Subjects & 1 & 2 & 3 & 4 & 5 & 6 & 7 & 8 & Total \\
\hline Arabic language and literature & 4 & 4 & 4 & 3 & 2 & 2 & 2 & 2 & 23 \\
\hline Turkish language and literature & 2 & 2 & 2 & 2 & 2 & 2 & 2 & 1 & 15 \\
\hline History of Islam & 2 & 2 & 2 & 2 & & & & & 8 \\
\hline History and history of philosophy & & & & & 2 & 2 & 2 & 2 & 8 \\
\hline Arithmeticandtheory & 3 & 3 & 3 & 2 & & & & & 11 \\
\hline Geometry & & & & 2 & 2 & 1 & & & 5 \\
\hline Theology & & & 1 & 2 & 1 & 1 & & & 5 \\
\hline Geography & 2 & 2 & 2 & 1 & 1 & & & & 8 \\
\hline Naturalhistory (estestvennaiaistoriia) & & & & & 1 & 1 & 1 & & 3 \\
\hline Drawingandcalligraphy & 2 & 2 & 1 & 1 & 1 & & & & 7 \\
\hline Russian & 12 & 12 & 12 & 12 & 12 & 3 & 3 & 2 & 68 \\
\hline Physics & 2 & 2 & 2 & & & & & & 6 \\
\hline EthicsandPsychology & & & & 1 & 1 & 1 & & & 3 \\
\hline Algebraandtrigonometry & & & & & 2 & 2 & 1 & 1 & 6 \\
\hline NaturalsciencesandChemistry & & & & & & & 4 & 4 & 8 \\
\hline Qur'an & 1 & 1 & & & & & & & 2 \\
\hline InterpretationofQur'an & & & & & & & 2 & 2 & 4 \\
\hline Hadith & & & & & & & 2 & 2 & 4 \\
\hline Figh & & & 1 & 1 & 4 & 4 & & & 10 \\
\hline Astronomy & & & & & & & & 1 & 1 \\
\hline Economy & & & & & & & 1 & 1 & 2 \\
\hline StoryofMukhammed'slife & & & & & & 1 & & & 1 \\
\hline Inheritancelaw & & & & & & & & 1 & 1 \\
\hline Pedagogy and methods of teaching & & & & 1 & & 2 & 2 & 1 & 6 \\
\hline Hygiene & & & & & & & & 1 & 1 \\
\hline Logic & & & & & & 1 & & 1 & 2 \\
\hline Accounting (inRussian) & & & & & & 1 & 1 & 1 & 3 \\
\hline \multicolumn{10}{|l|}{ French and German (upon request) } \\
\hline Total & 30 & 30 & 30 & 30 & 31 & 23 & 23 & 23 & 220 \\
\hline
\end{tabular}

The first thing to be noted is the increase in lessons per week-forty hours more with respect to the time-table of 1906. What factors contributed to this increase? First of all, two more years of study were added and the 
schooling now took not six but eight years. Together with the four years of mekteb the complete course was now twelve years of studies. Secondly, the Arabic and Turkic languages were now studied with the corresponding literature. Thirdly, religious subjects now occupied 35 hours of the teaching time against sixteen in the previous curriculum.

The famous specialist in Islamic studies N. Bobrovnikov used this curriculum in his "Note on the Question of the Spread of Russian Education among the Non-Russian Population of Central Asia" in order to demonstrate the changes in the Muslim school. Focusing closely on secular and religious subjects at the madrasah, he stated that

(...) he times of stagnation in a madrasah have passed... (it) can no longer be considered a hotbed of fanaticism. It has become the hotbed of something new, still unfamiliar to us, but this something is undoubtedly appealing to people (Note 6).

Shortcomings in teaching werenotof great importancesincetheorganizationof a madrasahwasnotrigidand, as we have seen, it was quite easy to change the curriculum if an improvement was needed. Several madrasahs in the Middle Volga region adopted the curriculum of the Bubi and Bobrovnikov was sure that these would be followed by the madrasahs of Central Asia.

Starting from the summer of 1908, Bubimadrasah opened unofficial three-month courses for male and female teachers. The subjects studied were mathematics, natural sciences (botany, zoology, chemistry and physics), geography, history and hygiene. The courses were purely theoretical, with no teaching practice. The number of young teachers coming to the courses increased yearly: if during the first year only twenty teachers came to Bubi, by the summer of 1909 there were already 64 people and in 1910 - 84. The teachers listened to lectures in pedagogy and methods of teaching, and studied lesson plans. This was very similar to the summer courses offered by the Tatar Teacher Training College in Kazan (Makhmutova, 2003). What should be noted however, for all the progressive character of teaching, is that neither the Bubi, nor the Mukhammadiiacurriculum had Tatar language classes. This was the question raised in 1911 at the second meeting devoted to Muslim education summoned by Ufa provincial zemstvo on 23 May 1911.

The participants at the meeting were the members of the Muslim fraction of the State Duma, teachers and representatives of the Ministry of Education. It was decided that the language of education in the Muslim primary school was to be the Tatar language. As regards Russian language skills, it was agreed that a school graduate was to be able to read and speak Russian, be able to paraphrase simple articles and write in a comprehensible way. It was deemed necessary to open separate Muslim teacher training schools with teaching in Russian and literary Tatar (Note 5). Commenting on the decisions of the Ufa zemstvo, Koblov draws the conclusion that it was taking the existing mekteb system as a basis and transforming it into a religious educational institution with a national character. In fact, for the sake of money, instead of opening new schools, madrasahs and mektebs were sometimes being transformed into schools with general education.

Stolypin's"Interministerial Conference on the Question of School Organization among the Non-Russian, Non-Orthodox and Non-Christian Population" (November 1910 to December 1911) concluded that the key to the solution to the problem of non-Russian education was an improvement in the cultural level of all the ethnic groups of the Russian empire, and even more so, that of the ethnic Russians. In other words, the solution was universal general literacy of the population which, if made available to all the ethnic groups of the empire, would gradually diminish, or even completely eliminate confessional schools. Secondly, all the confessions of the empire, as well as all the non-Russian languages, now became a part of the state educational system. Schooling in native languages, at least during the first two years of studies, was crucial, especially for the languages that for the moment lacked an alphabet and written literature (Steinwedel, 1999). It was important, Stolypin stressed, that the Russian language be taught both in state and private educational institutions. Without the Russian language, and the introduction of lessons in Russian history and geography, it was deemed impossible to make non-Russians understand, and live according to, state principles. However, the meeting of Kazan zemstvo with representatives of the Muslim population concerning the questions of Muslim Tatar education on 10-11 January 1911, came to a different conclusion.

Mullahs, editors of newspapers, teachers, representatives of school administration and merchants took part in the meeting. The outcomes of the meeting were as follows: there was unanimous support for the opening of Russian Tatar schools, but the innovation was to have a gradual character. Therefore, while such schools should be opened in every district, at first they should be model schools in order to engage the interest of the Tatar population. Secondly, the school day should be divided into two parts: in the morning Tatar students should study Tatar and basics of religion, and in the afternoon - the Russian language and other general education subjects. This was explained by the fact that it was difficult to study Tatar and Arabic languages and so it was 
necessary to dedicate the morning hours to the study of these subjects.

What was remarkable about Muslim Tatar schools, was that even the new-method schools remained confessional and not schools of general education in the full sense of the word. "...if the old school, based on religion, gave a solid ground for the spread of pan-Islamic ideas, and for the unification of Muslims on the basis of religion without distinction of nationality, the schools of new method can foster the development of national pan-Turkic ideas on thebasis of common language"(Koblov, 1916). This meant, in Koblov's opinion, that the school projected by the Muslim Tatars would not weaken "fanaticism", but would make it more conscious, encouraging small Muslim ethnic groups to unite between themselves. This "educated fanaticism" was much more dangerous that "illiterate fanaticism" which was developed by the old-method Muslim schools:

The graduates will not feel themselves to be Russian citizens but only followers of Islam and its prophets, whatever state they belong to. This school project leads to the creation of a state within the state, where the Muslim state is alien to Russia but lives at the expense of the empire. To help Muslims in this situation would not only mean to make an enemy, but even to strengthen him. (Koblov, 1916)

Bishop Andrei, calling the Tatar intelligentsia "our Young Turks", warned the public that they were taking the initiative in creating a "Russian Turkic State" (Rossiiskii Turkestan). For him, the Muslim desire to transfer mektebs and madrasahs from the control of Russian officials to the jurisdiction of the Spiritual Assembly reflected their intention to make this institution the "Ministry of the Turkic State" in the future.

After 1908, due to the tensions in the Ottoman empire and the Young Turk revolution, suspicion of all Muslim activities, schooling included, increased. Many madrasahs were accused of Pan-Turkism and of supporting Muslims in the Ottoman empire. Against this background, the Bubi brothers were arrested in 1911 and the madrasah was closed. Several qadimist mullahs testified against the brothers before and after the trial. For example, the mullah Ishmi-ishan had made a statement, on 17 December 1910, accusing the Bubi brothers of something they were scarcely guilty of:

I do not consider the pronunciation of letters to be the new method. The new method is teaching subjects that, according to the Qur'an should not be taught and the books that are used in the new-method madrasahs, are also against the Qur'an and the sharia....I talked to the people and I found out that the essence of the new method is as follows: we, Tatars, have lagged behind other peoples in education. We should learn not only religious subjects to become mullahs. Instead, we should overtake Russians in education, so that Tatars can get important positions in the government, as high as a Minister's position. Only then will we become strong and be able to claim our rights (Makhmutova, 2003).

It is clear that the last sentences of the report are very provocative, for the aim of the jadids, and the Bubi brothers among them, was solely to catch up with Russian and European progress. And while it is true that the jadids were willing to represent Muslims in the government and be able to defend their rights, the statement above reads as if the aim was to oust Russians from the highest positions in the government. The educational agenda of the Bubi madrasah was certainly more modest than these accusations.

Actions like the closing of the Bubi madrasah, made Muslims react and they summoned another congress in Buguruslan in 1912. The difference from the previous congresses in Kazanand Ufa was that the first twoweresummonedontheinitiative of the zemstvo, but the one in Buguruslan was summoned on the initiative of the Muslims themselves. Questionsofamore practical nature were discussed at the meeting, such as practical help to madrasah on the part of the zemstvo, unification of mekteb and madrasah programs and school management. The members of Buguruslan congress had little expectation of financial support for Muslim schools on the part of the state and hoped for help from the zemstvo. In the end it was decided, that trustees from the zemstvo would take part in the management of the madrasah.

The greatest achievement of the congress was the drafting of a unified program for mektebschools. Attempts had been made since the congress in Nizhnii Novgorod in 1906, such as the Essen village program in the district of Sarapul or the program of Muslim school teachers in Omsk. The Buguruslan program was accepted as the basis for all Muslim mektebs. As before it included the religious subjects, arithmetic, Turkish language, history and geography. The major difference was that there was a more detailed program of what material had to be taught in which school class. The general attitude to school for the Muslims of Russia was that it should help to preserve the national identity of the Tatars. In order to do so, it was essential for the school to bring up children in the spirit of Muslim religion. Secondly, children should study the national language and all general knowledge subjects should be also taught in the national language. Thirdly, it was important to have the school controlled by a secular body in the form of a board of trustees (Koblov, 1916). 


\section{Conclusion}

The authorities, both at the local level and in the capital, felt compelled to react to the Muslim educational reforms. On closer inspection of the situation, it became clear that the old problems remained. First of all, it was still difficult to control the teaching process at madrasah, primarily because there were simply too many of them, but also because the inspectors were afraid of being attacked and insulted. By 1913 there were 994 confessional schools in Kazan province (43 of them were teaching using the sound method and in another 25 there was teaching of general subjects). Secondly, most Muslim schools were still in transition, there was considerable confrontation between the new and the old madrasah and the status of the new schools was not at all clear to the authorities. In October of 1913the Vice-Governor of Kazan G. B. Petkevich reported to the Minister of Interior N. A. Maklakov:

The level of teaching itself [at the madrasah]is amateurish and leaves much to be desired. The teachers of new-method madrasahs are the first to be discontented with the results of such education. There is a great urge for national progress among Muslims as well as understanding of the role of schools in this matter, but they are also aware that the present-day madrasahs do not provide an adequate level of education, do not have clearly-defined aims, and do not belong to a certain type of school. The presence of about a thousand schools functioning quite by themselves, with almost no control, is certainly a threat to Russian statehood and requires taking immediate measures (Note 7).

Tatars were usually quick to assign to every school the status of madrasah. Yet, not every school functioned according to the generally accepted idea of what a madrasah was. It became clear that in order to control the process of Muslim schooling, and also what was taught, besides general education subjects, first of all the schools needed to be classified.

It was also necessary to differentiate between confessional and secular Muslim Tatar schools. Confessional schools should be the property of Muslim parishes and be controlled by loyal Muslim clergy. The schools that taught general subjects besides religion, were to be considered not a madrasah, but general schoolsand should follow the instructions for primary non-Russian schools. If it was not possible to assign a new Muslim madrasah the same status as schools for other non-Russians, it was to be considered a school of a different type that required a new legal status. Schools of this type were considered quite harmful, with the "scarcely visible propaganda of Pan-Islamism", which were constituting a "malignant tumour" on the body of society which was "to be cut out so that the atmosphere around us became pure again" (Note 8). Secular education for Tatars seemed to be a most undesirable phenomenon as far as the Russian authorities were concerned.

\section{References}

Alov, A. A. (1996). Islam in Russia (p. 52). Moscow.

Bennigsen, A. (1971). Islamic or Local Consciousness among Soviet Nationalities? In E. Allworth (Ed.), Soviet Nationality Problems. New York: Columbia University Press.

Dudoignon, S. A. (1997). Qu'est-ce que la "Qadimiya"? Éléments pour une sociologie du traditionalisme musulman, en Islam de Russie et en Transoxiane (au tournant des 19 et 20 siècles). In S. A. Dudoignon et al. (Eds.), L'Islam de Russie-Conscience communautaire et autonomie politique chez les Tatars de la Volga et de l'Oural depuis le 18e siècle (pp. 207-225). Paris: Maisonneuve et Larose.

Frank, A. J. (1998). Islamic Historiography and "Bulgar" Identity among the Tatars and Bashkirs of Russia. Leiden: Brill.

Iskhakov, D. M. (1997). Problems of formation and transformation of the Tatar nation. Kazan: n. p.

Karpat, K. (2001). The Politicization of Islam: Reconstructing Identity, State, Faith, and Community in the Late Ottoman State. New York: Oxford University Press.

Koblov, I.D. (1908). Dreams Tatar Muslims on confessional school: TipografiiaImperatorskogoUniversiteta.

Koblov, I. D. (1916). Confessional school of Kazan Tatars. Kazan: n. p.

Makhmutova, A. (2003). Lish 'tebe, narod, sluzhenie. Kazan: Magarif.

Naganawa, N. (1905). Molding the Muslim Community through the Tsarist Administration: Mahalla under the Jurisdiction of the Orenburg Mohammedan Spiritual Assembly after. Acta Slavica Iaponica, 23, 105-111.

Steindwedel, C. R. (1999). Invisible Threads of Empire: State, Religion, and Ethnicity in Tsarist Bashkiria, 1773-1917 (Unpublished doctoral dissertation). New York, USA: Columbia University. 


\section{Notes}

Note 1. RGIA, f. 796, op. 191, otd. 6, st. 3, d. 163, 11. 4-5 ob.

Note 2. RGIA, f. 821, op. 133, dd. 573, 576, 11. 235 ob-41.

Note 3. RGIA, f. 821, op. 8, d. 41, 1.154-154 ob.

Note 4. From the speech of a Muslim deputy Sadri Maksudov in the Third Duma, in Geraci, Robert P. (2001). Window on the East: National and Imperial Identities in Late Tsarist Russia. Ithaca and London: Cornell University Press. p. 291

Note 5. RGIA, f. 733, op. 176, d. 46, 1. 336.

Note 7. NART, f. 1, op. 4, d. 5482, 11. 122-128 ob.

Note 8. NART, f. 160, op. 1, d. 1768, 11. 10-13 ob.

\section{Copyrights}

Copyright for this article is retained by the author(s), with first publication rights granted to the journal.

This is an open-access article distributed under the terms and conditions of the Creative Commons Attribution license (http://creativecommons.org/licenses/by/3.0/). 